\title{
Determination of trophic relationships within a high Arctic marine food web using $\delta^{13} \mathrm{C}$ and $\delta^{15} \mathrm{~N}$ analysis*
}

\author{
Keith A. Hobson ${ }^{1,2}$, Harold E. Welch ${ }^{2}$ \\ ${ }^{1}$ Department of Biology, University of Saskatchewan, Saskatoon, Saskatchewan, Canada S7N 0W0 \\ ${ }^{2}$ Department of Fisheries and Oceans, Freshwater Institute, 501 University Crescent, Winnipeg, Manitoba, Canada R3T 2N6
}

\begin{abstract}
We measured stable-carbon $\left({ }^{13} \mathrm{C} /{ }^{12} \mathrm{C}\right)$ and/or nitrogen $\left({ }^{15} \mathrm{~N} /{ }^{14} \mathrm{~N}\right)$ isotope ratios in 322 tissue samples (minus lipids) representing 43 species from primary producers through polar bears Ursus maritimus in the Barrow Strait-Lancaster Sound marine food web during July-August, 1988 to 1990. $\delta^{13} \mathrm{C}$ ranged from $-21.6 \pm 0.3 \%$ for particulate organic matter (POM) to $-15.0 \pm 0.7 \%$ for the predatory amphipod Stegocephalus inflatus. $5^{15} \mathrm{~N}$ was least enriched for POM $(5.4 \pm 0.8 \%$ ), most enriched for polar bears $(21.1 \pm 0.6 \%$ ) and showed a step-wise enrichment with trophic level of $+3.8 \%$. We used this enrichment value to construct a simple isotopic food-web model to establish trophic relationships within this marine ecosystem. This model confirms a food web consisting primarily of 5 trophic levels. $\partial^{13} \mathrm{C}$ showed no discernible pattern of enrichment after the first 2 trophic levels, an effect that could not be attributed to differential lipid concentrations in food-web components. Although Arctic cod Boreogadus saida is an important link between primary producers and higher trophic-level vertebrates during late summer, our isotopic model generally predicts closer links between lower trophic-level invertebrates and several species of seabirds and marine mammals than previously established.
\end{abstract}

\section{INTRODUCTION}

The marine ecosystem of the Lancaster Sound region (LSR) of Canada's high Arctic is of major importance to a variety of marine birds and mammals as well as to several Inuit communities (Welch et al. in press). Over the last 2 decades, this area has received considerable attention from marine ecologists owing to its projected use as a transportation corridor and the potential development of the region's hydrocarbon and mineral reserves (Gaston \& Nettleship 1981, Bradstreet \& Cross 1982 , Welch et al. in press). These investigations indicated that the marine foodweb is relatively long, with polar bears Ursus maritimus presumably occupying a fifth trophic level. Arctic cod Boreogadus saida plays a critical role in the transfer of energy from lower trophic levels to marine birds and mammals (Bradstreet \& Cross 1982) but the role of lower trophic-level organisms (e.g. zooplankton, benthos) in overall processes of energy transfer remains poorly understood.

\footnotetext{
- Contribution No. 17 from the Resolute Marine Laboratory
}

Establishing trophic relationships within communities is a daunting task (see Paine 1988), particularly for polar marine ecosystems where year-round sampling of food-web components may often be impossible. Studies of trophic organization depend primarily on stomach content analyses for placement of species. As a result, trophic models are often based on an instant in time and are particularly susceptible to limitations of both temporal and spatial scaling (Paine 1988). Recently, it has been demonstrated that the measurement of the abundances of naturally occurring stable isotopes of carbon $\left({ }^{13} \mathrm{C} /{ }^{12} \mathrm{C}\right)$ and particularly nitrogen $\left({ }^{15} \mathrm{~N} /{ }^{14} \mathrm{~N}\right)$ can provide trophic level information in marine food webs (reviewed by Fry \& Sherr 1988, Owens 1988). This approach is based on the observation that, under certain circumstances, these isotopes undergo a predictable step-wise enrichment between prey and consumer tissues (e.g. Rau 1982, Wada et al. 1987. Dickson 1986, Fry 1988). By measuring the isotopic concentrations of tissues of a suite of consumers it may thus be possible to determine relative or absolute trophic positions within a marine community. 
In such cases, the stable isotope approach offers distinct advantages over conventional dietary techniques since (1) trophic-level information is based on assimilated, not just ingested foods and (2) trophic positions represent long-term averages, depending on the metabolic rate of the tissue being measured (Tieszen et al. 1983).

In this paper we present the results of isotopic analyses of components of an Arctic marine food-web. Previous studies have used the stable isotope technique to establish patterns of food web structure in Arctic waters (e.g. McConnaughey \& McRoy 1979, Dunton et al. 1989) but have not considered complete food webs that include the roles of higher-level carnivores such as seabirds, whales, seals and polar bears. We isotopically measured samples from primary producers through polar bears. Our objectives were to (1) evaluate the usefulness of the stable-isotope technique in this marine system by comparing isotopic data to known trophic pathways and (2) to establish the trophic status of individual organisms whose feeding ecology is poorly understood.

\section{STUDY AREA AND METHODS}

Samples were collected in July and August, 1988 to 1990, primarily in the Barrow Strait-Lancaster Sound region of the Northwest Territories, bounded by Resol-

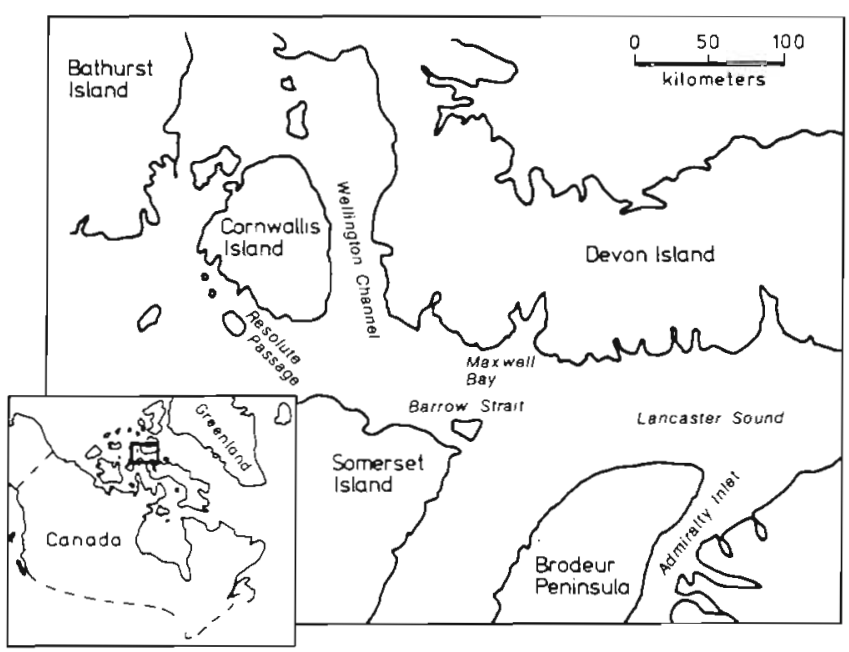

Fig. 1. The Barrow Strait-Lancaster Sound study area used for sample collection

ute Passage to the west and Maxwell Bay on south Devon Island to the east (Fig. 1). A sample of narwhal Monodon monoceros was obtained from the ice edge near Admiralty Inlet. Zooplankton samples were obtained by horizontal towing using a $0.8 \mathrm{~mm}$ plankton net at depths over 80 to $100 \mathrm{~m}$ in Resolute Passage. Arctic cod were caught by otter trawl and trap nets set in Resolute and Allen Bays. Other benthic organisms were collected by diving and trawling. Copepod, mysid and Parathemisto samples were held live overnight in filtered seawater to allow evacuation of gut contents prior to isotopic analysis. Particulate organic matter (POM) samples were obtained from Resolute Passage in late July 1989 and 1990 by filtering 2 to $10 \mathrm{l}$ of seawater through a $0.06 \mathrm{~mm}$ screen and then onto precombusted GFF glass-fiber filters. Tissue samples from adult marine birds were obtained by at-sea collections and those of marine mammals from local Inuit hunters. Seals, whales and bears were adults but ages were not available. All samples were stored frozen at $20^{\circ} \mathrm{C}$.

Lateral muscle samples were removed from fish, pectoral muscle was taken from birds and miscellaneous muscle tissue salvaged from hunter-killed marine mammal remains. Muscle samples were later freezedried and powdered using an analytical mill. Muscle was removed also from larger amphipods but tissues from smaller zooplankton were obtained by freezedrying a suitable number $(>10)$ of whole specimens, powdering them and then treating the combined sample with $2 \mathrm{~N} \mathrm{HCl}$ to remove carbonates. After drying $\left(60^{\circ} \mathrm{C}\right)$ the remaining sample was stored without rinsing for later isotopic analysis. POM samples were treated similarly for carbonates. Because organisms may vary in their concentrations of isotopically lighter lipids (Attwood \& Peterson 1989) lipids were removed from all samples using a Soxhlet apparatus for 4 to $6 \mathrm{~h}$ with chloroform as a solvent (see also Monteiro et al. 1991, Sholto-Douglas et al. 1991).

Samples for ${ }^{13} \mathrm{C}^{12} \mathrm{C}$ analysis were loaded into Pyrex tubes with $1 \mathrm{~g}$ of wire-form $\mathrm{CuO}$ and silver foil, sealed under vacuum and combusted at $550^{\circ} \mathrm{C}$ for at least $6 \mathrm{~h}$. We found no difference in isotopic results between samples combusted in this way and those combusted at higher temperatures in Vycor tubes (Swerhone et al. 1991). Samples for ${ }^{15} \mathrm{~N}^{14} \mathrm{~N}$ analysis were converted to ammonia by Kjeldahl reaction and then to $\mathrm{N}_{2}$ gas using $\mathrm{LiBrOH}$ (Porter \& O'Dean 1977). Carbon dioxide and nitrogen gas were analyzed using a Micromass 602E mass spectrometer. Stable isotope concentrations were expressed in $\delta$ notation according to the following

$$
\delta X=\left[\left(R_{\text {sample }} / R_{\text {standard }}\right)-1\right] \times 1000
$$

where $X$ is ${ }^{13} \mathrm{C}$ or ${ }^{15} \mathrm{~N}$ and $R$ is the corresponding ratio ${ }^{13} \mathrm{C} /{ }^{12} \mathrm{C}$ or ${ }^{15} \mathrm{~N} /{ }^{14} \mathrm{~N} . R_{\text {standard }}$ for ${ }^{13} \mathrm{C}$ and ${ }^{15} \mathrm{~N}$ are the PDB standard and atmospheric $\mathrm{N}_{2}$ (AIR), respectively. Replicates using glycine (nitrogen) and lentil (carbon) standards indicate analytical errors of \pm 0.1 and $0.3 \%$ 
for carbon and nitrogen samples, respectively (see also Bremner \& van Kessel 1990).

\section{RESULTS}

We found a considerable range in both carbon and nitrogen stable-isotope concentrations throughout the food web (Table 1). Stable nitrogen isotope ratios varied from $4.9 \%$ for a POM sample to $21.9 \%$ for a polar bear muscle sample. The lowest $\delta^{13} \mathrm{C}$ value was similarly found for a POM sample $(-22.0 \%$ ) but the highest value of $-15.0 \%$ occurred in muscle tissue of the carnivorous amphipod Stegocephalus inflatus.

Stable-nitrogen isotope values for food web samples were not obviously correlated with $\delta^{13} \mathrm{C}$ values after the first trophic shift from primary producers to filter feeders (Fig. 2). In contrast, $\delta^{15} \mathrm{~N}$ values showed a steady enrichment with increasing trophic position (Table 1, Fig. 3). An estimate of the trophic enrichment factor for nitrogen can be obtained by examining isotopic differences between consumers and their diets in cases where such a trophic relationship is well established. Polar bears in the LSR feed almost exclusively on ringed seals Phoca hispida (Stirling \& McEwan 1975, Hammill \& Smith 1991) and a mean trophic shift of $+3.8 \%$ occurred between muscle tissue of these 2 species. This value also corresponded to the mean difference between the copepod Calanus hyperboreus and its primary food, POM (Conover \& Cota 1985, Head et al. 1985, 1988) indicating that an isotopic model based on this trophic enrichment factor was possibly applicable throughout the food web. However, recent research using captively raised, piscivorous birds indicates that the ${ }^{15} \mathrm{~N}$ isotopic fractionation factor between bird diet and muscle tissue is less than that assumed here for the rest of the marine food web (Mizutani et al. 1991, Hobson \& Clark 1992). This difference may be due to the fact that birds produce uric acid rather than urea (but see Minagawa \& Wada 1984). Using tissues of an adult cormorant held in captivity on a known isotopic diet for 23 yr, Mizutani et al. (1991) provide an estimate of the muscle $\delta^{15} \mathrm{~N}$ enrichment value of $+2.4 \%$. We used this value to predict trophic positions of marine birds. For all other components of the marine food web we used an enrichment value of $+3.8 \%$ according to the relationship:

$$
\mathrm{TL}=1+\left(D_{\mathrm{m}}-5.4\right) / 3.8
$$

where TL is the trophic level of a consumer and $D_{m}$ the $\delta^{15} \mathrm{~N}$ value of the consumer's muscle tissue (\%o). For example, this model predicts polar bears with a mean muscle $\delta^{15} \mathrm{~N}$ value of $21.1 \%$ occupy TL 5.1 and copepods with mean $\delta^{15} \mathrm{~N}$ values of $9.2 \%$ occupy TL 2 (Table 1, Fig. 3).

\section{DISCUSSION}

\section{Patterns of carbon isotope abundance}

Despite ${ }^{13} \mathrm{C}$ trophic enrichments of about $1 \%$ reported for other marine systems (e.g. Rau et al. 1983, Mills et al. 1984, Dickson 1986) and single feeding steps (DeNiro \& Epstein 1978, Haines \& Montegue 1979, Rau \& Anderson 1981), we found no discernible enrichment after the level of particulate feeding invertebrates such as bivalves and lower trophic-level zooplankton. Thus, we were unable to construct a trophiclevel model using carbon, at least for higher-order consumers. These results are similar to those found by Fry (1988) for Georges Bank and by Wada et al. (1987) for an Antarctic marine ecosystem. Lipids are depleted in ${ }^{13} \mathrm{C}$ compared to whole organisms or proteins (Parker 1964, Gormly \& Sackett 1977) and their presence in samples can shift $\delta^{13} \mathrm{C}$ values in a negative direction (e.g. Lee \& Hirota 1973). Wada et al. (1987) suggested that the absence of a step-wise enrichment of ${ }^{13} \mathrm{C}$ throughout an Antarctic marine food web was likely due to differential lipid content in the organisms they measured. Fry (1988) similarly did not remove lipids prior to isotopic analysis of samples from Georges Bank. Because lipids were removed, our study suggests that the lack of a strong ${ }^{13} \mathrm{C}$ enrichment effect at higher trophic levels is not necessarily due to the effect of lipids.

The mean ${ }^{13} \mathrm{C}$ value for POM of $-23.5 \%$ is similar to values reported for other marine ecosystems (McConnaughey \& McRoy 1979, Tan \& Strain 1983, Mills et al. 1984, Dickson 1986) and, although the number of samples was too small for statistical comparison, this value appeared to change little between years. Ice algae and kelp showed more enriched $\delta^{13} \mathrm{C}$ values compared to POM and this effect could potentially be used to trace the relative importance of these primary producers to herbivores.

Among bivalves, Macoma calcarea showed the greatest enrichment in ${ }^{13} \mathrm{C}$ relative to POM. Unlike the other species examined, $M$. calcarea is primarily a deposit feeder (Ockelmann 1958) and likely consumes carbon of detrital origin as well as phytoplankton. In their isotopic study of the food-web structure of the Bering Sea, McConnaughey \& McRoy (1979) similarly reported high carbon enrichment values for the deposit-feeding bivalve Yoldia limatulata (see also Haines 1976) and attributed this effect to stronger isotope fractionation by deposit feeders or to longer food webs involving bacterial and meiofaunal intermediates,

Previous isotopic investigations of zooplankton and benthic invertebrates in Alaskan coastal waters suggests an east-west enrichment in consumer $\delta^{13} \mathrm{C}$ values 
Table 1. Stable-isotopic compositions of selected components of the Barrow Strait-Lancaster Sound marine food web. Values are given as $\mathrm{X} \pm \mathrm{SD}$ in \%. Trophic level is based on isotopic model using a ${ }^{15} \mathrm{~N}$ trophic enrichment values of $+2.4 \%$ for marine birds and $+3.8 \%$ for all other organisms (see text)

\begin{tabular}{|c|c|c|c|c|}
\hline Sample & $n^{b}$ & $\delta^{13} \mathrm{C}$ & $\delta^{15} \mathrm{~N}$ & $\begin{array}{c}\text { Trophic } \\
\text { level }\end{array}$ \\
\hline \multicolumn{5}{|l|}{ Primary producers } \\
\hline Particulate organic matter & 5 & $-21.6 \pm 0.3$ & $5.4 \pm 0.8$ & 1 \\
\hline Ice algae & 2 & $-20.7 \pm 0.9$ & $7.5 \pm 0.1$ & \\
\hline \multicolumn{5}{|l|}{ Kelp } \\
\hline Laminaria solidungula & 5 & $-20.1 \pm 0.4$ & $7.1 \pm 1.3$ & \\
\hline L. longicruris & 5 & $-20.0 \pm 0.6$ & $7.6 \pm 0.9$ & \\
\hline Agarum cribosum & 5 & $-20.1 \pm 0.3$ & $7.7 \pm 0.3$ & \\
\hline Alaria sp. & 5 & $-19.4 \pm 0.5$ & $9.4 \pm 0.5$ & \\
\hline \multicolumn{5}{|l|}{ Invertebrates } \\
\hline \multicolumn{5}{|l|}{ Barnacles } \\
\hline Balanus sp. & 3 & $-20.8 \pm 0.4$ & $10.4 \pm 0.3$ & 2.3 \\
\hline \multicolumn{5}{|l|}{ Bivalves } \\
\hline Mya truncata & 7 & $-19.0 \pm 0.4$ & $9.5 \pm 0.7$ & 2.1 \\
\hline Serripes groenlandica & 7 & $-18.7 \pm 0.4$ & $8.9 \pm 0.8$ & 1.9 \\
\hline Hiatella arctica & 10 & $-18.9 \pm 0.8$ & $9.8 \pm 0.5$ & 2.2 \\
\hline Macoma calcarea & 4 & $-17.5 \pm 0.5$ & $10.8 \pm 0.5$ & 2.4 \\
\hline Musculus discors & 4 & $-20.5 \pm 0.5$ & $7.9 \pm 0.4$ & 1.7 \\
\hline \multicolumn{5}{|l|}{ Mollusks } \\
\hline Buccinum sp. & 5 & & $12.6 \pm 0.7$ & 2.9 \\
\hline \multicolumn{5}{|l|}{ Echinoderms } \\
\hline Crossaster papposus & 3 & & $16.1 \pm 1.0$ & 3.8 \\
\hline Leptasterias sp. & 3 & & $11.5 \pm 0.6$ & 2.6 \\
\hline Unident cucumber & 3 & $-19.7 \pm 1.2$ & $9.5 \pm 0.5$ & 2.1 \\
\hline Strongylocentrotus sp. & 3 & $-16.5 \pm 0.3$ & $9.9 \pm 0.3$ & 2.2 \\
\hline \multicolumn{5}{|l|}{ Copepods } \\
\hline Calanus hyperboreus & $6^{*}$ & $-20.4 \pm 0.4$ & $9.2 \pm 0.5$ & 2.0 \\
\hline \multicolumn{5}{|l|}{ Mysids } \\
\hline Mysis oculata & $2 \cdot$ & & $10.3 \pm 0.3$ & 2.3 \\
\hline \multicolumn{5}{|l|}{ Amphipods } \\
\hline Rozinante fragilis & $5^{*}$ & $-19.8 \pm 0.5$ & $11.5 \pm 0.3$ & 2.6 \\
\hline Gammarus wilkitzkii & 5 & $-19.1 \pm 0.4$ & $11.5 \pm 0.3$ & 2.6 \\
\hline Parathemisto libellula & $6^{\circ}$ & $-20.3 \pm 0.4$ & $11.7 \pm 0.7$ & 2.7 \\
\hline Onisimus glacialis & $4^{*}$ & $-18.2 \pm 1.1$ & $11.4 \pm 0.5$ & 2.6 \\
\hline Stegocephalus inflatus & 5 & $-15.0 \pm 0.7$ & $15.1 \pm 0.6$ & 3.6 \\
\hline \multicolumn{5}{|l|}{ Anenomes and ctenophores } \\
\hline Mertensia ovum & $5 \cdot$ & $-19.8 \pm 0.5$ & $13.9 \pm 0.5$ & 3.2 \\
\hline Anenome urticina & 3 & $-18.9 \pm 0.5$ & $14.0 \pm 0.4$ & 3.3 \\
\hline \multicolumn{5}{|l|}{ Decapods } \\
\hline Lebbeus polaris & 5 & $-16.9 \pm 0.3$ & $14.5 \pm 0.3$ & 3.4 \\
\hline \multicolumn{5}{|l|}{ Fish $^{a}$} \\
\hline Boreogadus saida (48-247) & 26 & $-18.9 \pm 1.0$ & $15.2 \pm 0.7$ & 3.6 \\
\hline Boreogadus saida $(14-16)$ & $1^{\cdot}$ & -19.8 & 11.1 & 2.5 \\
\hline Gymnellus virides (101-156) & 4 & $-15.7 \pm 0.2$ & $16.2 \pm 0.5$ & 3.8 \\
\hline Liparis sp. $(46-125)$ & 4 & $-17.4 \pm 0.5$ & $15.0 \pm 0.4$ & 2.5 \\
\hline Icelus bicornis (39-81) & 4 & $-17.1 \pm 0.4$ & $14.6 \pm 1.5$ & 3.4 \\
\hline Myoxocephalus scorpiodes (92-145) & 1 & -18.1 & 15.2 & 3.6 \\
\hline \multicolumn{5}{|l|}{ Marine birds } \\
\hline Cepphus grylle & 25 & $-17.3 \pm 1.2$ & $15.4 \pm 0.7$ & 3.9 \\
\hline Uria lomvia & 25 & $-18.4 \pm 0.6$ & $15.8 \pm 0.7$ & 4.1 \\
\hline Fulmarus glacialis & 25 & $-19.2 \pm 0.9$ & $15.3 \pm 0.9$ & 3.9 \\
\hline Rissa tridactyla & 25 & $-18.3 \pm 0.7$ & $15.4 \pm 0.9$ & 4.0 \\
\hline Larus hyperboreus & 25 & $-17.6 \pm 0.5$ & $17.0 \pm 0.9$ & 4.4 \\
\hline
\end{tabular}


Table 1 (continued)

\begin{tabular}{|c|c|c|c|c|}
\hline Sample & $\mathrm{n}^{\mathrm{b}}$ & $\delta^{13} \mathrm{C}$ & $\partial^{15} \mathrm{~N}$ & $\begin{array}{c}\text { Trophic } \\
\text { level }\end{array}$ \\
\hline \multicolumn{5}{|l|}{ Marine mammals } \\
\hline Odobenus rosmarus & 6 & $-17.8 \pm 0.3$ & $12.5 \pm 0.6$ & 2.9 \\
\hline Phoca hispida & 9 & $-17.3 \pm 0.7$ & $17.3 \pm 1.1$ & 4.1 \\
\hline Erignathus barbatus & 4 & $-16.6 \pm 0.5$ & $16.8 \pm 0.2$ & 4.0 \\
\hline Monodon monoceros & 4 & $-18.0 \pm 0.4$ & $15.8 \pm 0.7$ & 3.7 \\
\hline Delphinapterus leucas & 6 & $-18.1 \pm 0.5$ & $16.6 \pm 0.6$ & 3.9 \\
\hline Ursus maritimus & 3 & $-18.0 \pm 0.6$ & $21.1 \pm 0.6$ & 5.1 \\
\hline
\end{tabular}

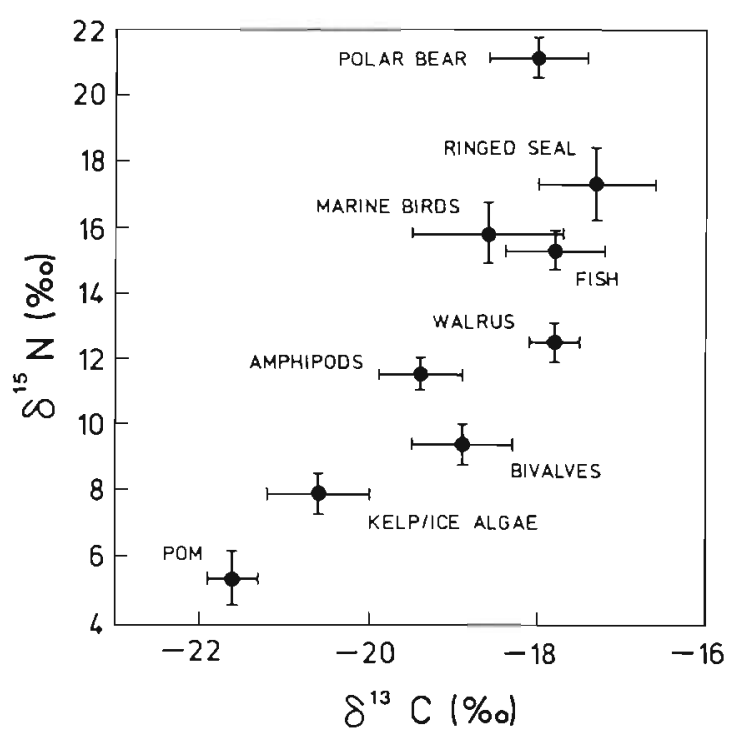

Fig. 2. Relationship of $\delta^{13} \mathrm{C}$ and $\delta^{15} \mathrm{~N}$ values of groups of marine food-web organisms from the Barrow Strait-Lancaster Sound study area. Amphipod sample excludes Stegocephalus inflatus and marine-bird sample excludes glaucous gull. Sample sizes are as per Table 1

(reviewed by Dunton et al, 1989). Calanoid copepods, for example, range from -25 to $-27 \%$ in the eastern Beaufort sea and -20.7 to $-21.1 \%$ in the north Bering and south Chukchi seas. Furthermore, Rau et al. (1982) found depletions in plankton $\delta^{13} \mathrm{C}$ values with increasing latitude. The average $\delta^{13} \mathrm{C}$ value of $-20.4 \%$ for calanoid copepods in Lancaster Sound suggests that such isotopic gradients do not proceed noticeably either northward or eastward into Central high-Arctic waters. However, because other researchers did not remove lipids from their samples prior to isotopic analysis, their isotopic values may not be comparable to ours.

\section{Patterns of nitrogen isotope abundance}

The mean $\delta^{15} \mathrm{~N}$ value of $5.4 \%$ for POM in the LSR is similar to average values found at other northern ocean sites (Minagawa \& Wada 1984, Dickson 1986, Fry 1988, Owens 1988; see also Harrigan et al. 1989) and suggests that nitrate is not limiting to primary producers (Wada et al. 1987). Similarly, our nitrogen trophic enrichment value of $+3.8 \%$ is within the range of estimates of 3 to $4 \%$ derived for isotopic models of marine food web structure elsewhere (Minagawa \& Wada 1984, Fry 1988, Hobson \& Montevecchi 1991). Sholto-Douglas et al. (1991) recently reported higher nitrogen trophic-enrichment values of +4.2 to $+4.9 \%$ for pelagic fish in the Southern Benguela Ecosystem. However, our model can only be considered an approximation to real trophic relationships in this system and further studies are required to establish more precisely $\delta^{15} \mathrm{~N}$ enrichment factors between consecutive trophic levels. It is important to note that the substrate type analysed isotopically differed, depending on the organism measured. Whole biomass (less lipids) of POM, copepods and small crustaceans were used compared to only fat-extracted muscle of larger fauna. Thus, to expect a consistent isotopic enrichment factor between all trophic levels is inappropriate and we reiterate that our nitrogen fractionation value of $+3.8 \%$ can only be considered an integrated average over the entire food web. We expect further refinements to our simple model as our understanding of specific isotopic fractionation factors between trophic levels improves.

The isotopic model confirms previous estimates of a food web consisting primarily of 5 trophic levels (Bradstreet \& Cross 1982, Welch et al. in press). However, further isotopic analysis of the benthic component of this system may reveal a longer food web (e.g. McConnaughey \& McRoy 1979). Our isotopic model is also consistent with a system that is driven by phyto- 


\section{Trophic level}

$\begin{array}{lllr}1 & 3 & 4 & 5 \\ 1 & 1 & 1\end{array}$

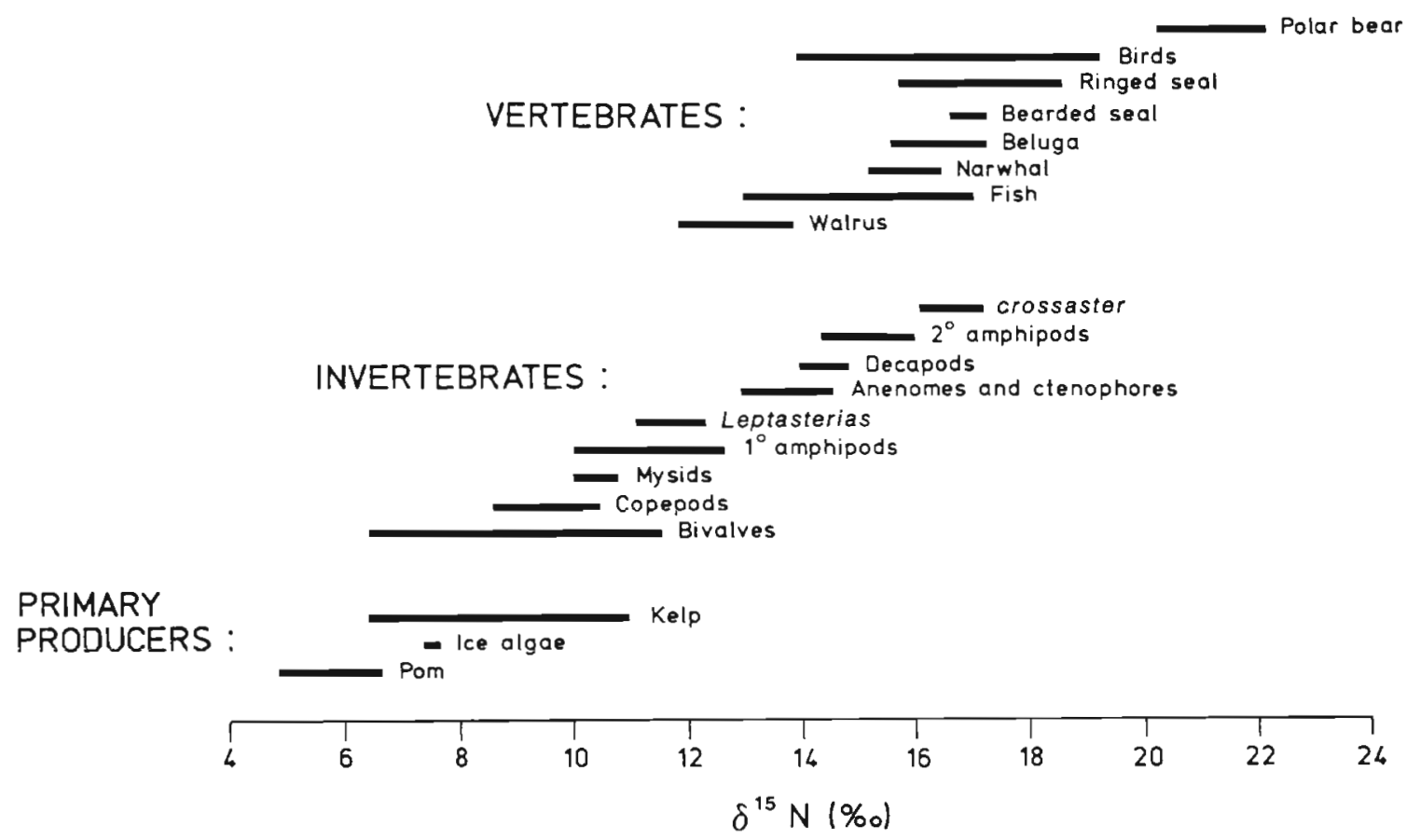

Fig. 3. Ranges of $\delta^{15} \mathrm{~N}$ values for marine organisms from Barrow Strait-Lancaster Sound and their associated trophic positions according to an isotopic model using a trophic enrichment value of $+3.8 \%$ (not applicable to marine birds)

plankton, at least during the summer months. Kelp and ice algae have mean $\delta^{15} \mathrm{~N}$ values approximately $2 \%$ higher than POM and we predict that significant input from these sources would result in higher $\delta^{15} \mathrm{~N}$ values for epibenthic fauna than those found here. Welch et al. (in press) calculated that ice algae fix only about $10 \%$ and kelp $1 \%$ of the total primary production in Barrow Strait and Lancaster Sound. Controlled laboratory studies are required, however, to determine isotopic fractionation values between primary producers and herbivores in this system to better ascertain the seasonal importance of carbon derived from various sources of primary production.

Invertebrates occupied a broad range of isotopic trophic positions ranging from suspension particle feeders such as copepods, barnacles and bivalves through predatory echinoderms or amphipods such as Stegocephalus inflatus. Dunton et al. (1989) obtained $\delta^{15} \mathrm{~N}$ measurements for omnivorous gastropods Buccinum spp. ranging from $13.8 \%$ in the Bering Sea to $15.2 \%$ in the eastern Beaufort Sea. Whereas further comparisons are needed, the mean $\delta^{15} \mathrm{~N}$ value of $12.6 \%$ for Buccinum suggests an isotopic composition of the benthos more similar to that of the Bering than the
Beaufort Sea. The Bering Sea has a much richer benthos that is more closely coupled to primary production than does the Beaufort since much primary production escapes grazing by zooplankton and falls to the seafloor (Grebmeier et al. 1988, Dunton et al. 1989). It is suspected that the same is true for this study area. Mean annual primary production rates in Resolute Passage are about $128 \mathrm{~g} \mathrm{C} \mathrm{m}^{-2} \mathrm{yr}^{-1}$ and in Barrow Strait 54 $\mathrm{g} \mathrm{C} \mathrm{m}^{-2} \mathrm{yr}^{-1}$ (Welch et al. in press), typically higher than that of the Beaufort Sea (Alexander 1974), but still less than that for the Bering Sea. Further isotopic comparisons of benthic omnivores from this and other areas might prove useful in establishing how closely primary production is coupled with benthic productivity.

The 2 starfish, Crossaster papposus and Leptasterias $s p$, differed by about one trophic level. According to D'yakonov (1950), C. papposus is a voracious predator which feeds mainly on molluscs, other echinoderms and occasionally anemones. D'yakonov's description is consistent with the higher $\delta^{15} \mathrm{~N}$ enrichment found for this species. In contrast, our isotopic data suggests that Leptasterias feeds primarily as a deposit feeder.

Four genera of amphipods, Rozinante, Gammarus, Parathemisto and Onisimus, showed very similar $\delta^{15} \mathrm{~N}$ 
values. According to our model, these amphipods occupied an average trophic level of 2.6 and likely consumed a mixed diet of copepods, animal detritus and primary production. This finding is consistent with stomach content analyses performed on the latter 3 genera by Bradstreet \& Cross (1982). Little is known of the feeding ecology of Rozinante fragilis. However, relative to other carnivorous species in this genus, it has smaller gnathopods and was observed in association with landfast ice where it likely fed on algae as well as zooplankton (K. Conlan, National Museum, Ottawa, pers. comm.). Consistent with their predatory niches, anemones, ctenophores, decapods and the amphipod Stegocephalus inflatus showed enriched isotopic values compared to lower trophic level invertebrates.

Juvenile and adult Arctic cod feed on a mixed diet of copepods and amphipods (Bradstreet et al. 1986) with larger fish apparently taking higher proportions of the larger prey items (Bohn \& McElroy 1976). However, the isotopic data for cod of lengths ranging from 48 to 247 $\mathrm{mm}$ are consistent with an average diet primarily of amphipods. Larger sample sizes of juvenile $(<100 \mathrm{~mm}$ ) cod are needed to confirm isotopically whether the diet of cod changes trophically with age (Bohn \& McElroy 1976) in our study area. Isotopic measurement of the composite sample of young-of-the-year ( $\mathrm{Y}-\mathrm{O}-\mathrm{Y}) \mathrm{cod}$ suggests that this age class fed primarily on copepods as well as prey from lower trophic levels (e.g. POM, algae). This confirms previous studies (summarized by Bradstreet et al. 1986) on the diet of $Y-O-Y \operatorname{cod}$ in our study area that identified copepods as the main prey item.

Ringed seals are year-round residents in Barrow Strait but the muscle isotopic data reflect an integration of diet only during the late spring to mid-summer period. This estimate is based on an incomplete knowledge of isotopic turnover rates in marine mammals but muscle tissue likely provides an estimate of integrated diet over a period of about 4 to $6 \mathrm{wk}$ (Tieszen et al. 1983) and so best reflects summer diet at our highlatitude study site. In general, ringed seals are opportunistic and feed on prey ranging from mysids and amphipods to larger fishes, particularly Arctic cod (reviewed by Bradstreet et al. 1986). According to Welch et al. (in press), the annual average ingestion by ringed seals in Barrow Strait is 60\% Arctic cod, 25\% hyperiid amphipods (Parathemisto), and 15\% gammarid amphipods, with cod being taken primarily in late summer and autumn (see also Finley 1978). Our isotopic model based on muscle predicts that marine mammals feeding exclusively on diets of amphipods and Arctic cod should show $\delta^{15} \mathrm{~N}$ muscle tissue values close to 15.3 and $19.0 \%$, respectively. Assuming only these trophic options, the mean $\delta^{15} \mathrm{~N}$ tissue value of
$17.3 \%$ for ringed seal tissue suggests an average summer diet comprised of approximately $54 \%$ cod and confirms a substantial dietary input of invertebrates. We predict that seals taken later in the autumn, after the major onshore movement of Arctic cod (Bradstreet et al. 1986, Hobson and Welch in press), will show tissue isotope values more enriched in ${ }^{15} \mathrm{~N}$, reflecting the higher proportion of cod in their diets. Furthermore, seals may change their trophic position depending on age, thus the isotopic analysis of various age classes of seals would prove informative.

Beluga whales Delphinapterus leucas, narwhal and, to a lesser extent, walrus Odobenus rosmarus and bearded seals Erignathus barbatus, are migratory and move into this area primarily during the late spring and early summer (Sergeant \& Hay 1978). This may complicate interpretation of isotopic data if animals move between areas of differing isotopic compositions (e.g. Schell et al. 1989). However, the isotopic model for the LSR may apply more generally to other portions of the range of these species in the eastern Arctic and western north Atlantic (see Hobson \& Montevecchi 1991). In the LSR, walrus feed primarily on bivalves (Welch et al. in press) and this is reflected in their lower $\delta^{15} \mathrm{~N}$ values compared to other marine mammals (Table 1). The bearded seal is primarily a benthic feeder and is known to take a broad range of invertebrates as well as fish including sculpins (Cottidae) and Arctic cod (Finley \& Evans 1983). Our model suggests a summer diet for this species consisting predominantly of prey of lower trophic level than Arctic cod or benthic fish.

Beluga whale movement into the study area coincides with the onshore movement of Arctic cod in late summer. Although winter diet is not known, stomach content analyses suggest that beluga whales feed almost exclusively on cod in the Barrow Strait area during the summer (Bain \& Sekerak 1978, Bradstreet et al. 1986). The isotopic data suggest a lower trophic position for this species than one consistent with an exclusive diet of cod. Similarly, narwhal apparently feed on Arctic cod and bottom-dwelling fish such as halibut (Bradstreet et al. 1986, Finley \& Gibb 1982) in the LSR, and yet the isotopic data again suggest a substantial contribution of lower trophic-level prey. Whereas it is possible that the $+3.8 \%$ trophic enrichment factor may not apply equally to all marine mammals, we suggest that lower trophic-level organisms that are not easily detected by stomach sample analysis constitute a significant portion of the diets of these whales during summer. Bradstreet \& Cross (1982) determined that narwhal taken east of the study site fed, apart from fish, also on squid and pelagic crustaceans (Boreomysis spp., Hymenodora decapods). Other researchers also report substantial crustacean contributions to the diets of some inshore-feeding narwhal 
(reviewed by Reeves \& Tracey 1980). Both beluga and narwhal are capable of diving to depths in excess of $400 \mathrm{~m}$ (Finley \& Gibb 1982, Ridgeway et al. 1984) where they may feed on benthic organisms. Alternatively, squid with stable-nitrogen isotopic compositions in the range 11 to $12 \%$ have been recorded off Newfoundland and George's Bank (Hobson \& Montevecchi 1991) and so whales consuming significant amounts of this prey would show lower $\delta^{15} \mathrm{~N}$ tissue values than consumers of Arctic cod

All of the seabirds examined in this study are known to prey on both Arctic cod and zooplankton, particularly the amphipod Parathemisto libellula (Gaston \& Nettleship 1981, Bradstreet \& Cross 1982, Hobson unpubl.). Assuming dietary inputs from only cod and $P$. libellula, muscle isotope values of black guillemots Cepphus grylle, thick-billed murres Uria lomvia, northern fulmars Fulmarus glacialis and black-legged kittiwakes Rissa trydactyla indicate a relative dependence on Arctic cod ranging approximately from $22 \%$ for fulmars and guillemots to $44 \%$ for murres. Copepods are an important prey item of northern fulmars (Bradstreet \& Cross 1982) and since they occupy a lower trophic position than $P$. libellula, the above is likely an underestimate of the contribution of cod to fulmar diets. Similarly, we cannot apply this simple 2prey approach to glaucous gulls since they are known to consume significant quantities of higher trophiclevel prey than cod (e.g. seabird eggs and chicks). Such a diet is consistent with their enriched $\delta^{15} \mathrm{~N}$ values compared to other seabirds. As with our findings for narwhal and beluga whales, the present isotopic investigation suggests that seabirds in Barrow Strait and Lancaster Sound consume more invertebrates than previously established through conventional dietary studies (e.g. Gaston \& Nettleship 1981, Bradstreet \& Brown 1985). This closer link with lower trophic-level prey is similar to that suggested by Sanger (1987) for seabirds in the Gulf of Alaska.

Previous dietary investigations in this marine system have emphasized the critical importance of Arctic cod in the transfer of energy from primary producers to higher level vertebrates (Bradstreet \& Cross 1982). Our isotopic investigations suggest that, although Arctic cod are an important component in the marine food web, lower trophic level invertebrates also play a critical role in this process of energy coupling. Further isotopic investigations using $\delta^{15} \mathrm{~N}$ measurements, designed to monitor seasonal or year-round dependence on invertebrates by various age classes of marine birds and mammals should further clarify the nature of energy transfer in this and adjacent boreal systems. Certainly, the isotopic analysis of several tissue types with varying protein turnover rates would provide time-integrated dietary information reflecting both short- and long-term periods of assimilation (Tieszen et al, 1983, Hobson \& Sealy 1991). Such isotopic studies will help to clarify similarities and differences in food web structure between Arctic and Antarctic marine systems and the relative roles of lower trophic level invertebrates in each (e.g. Rau et al. 1992; preceding article).

Acknowledgements. We thank the Polar Continental Shelf Project for logistical support. Financial support to KAH was provided by The Science Institute of the Northwest Territories, The Northern Studies Training Program, a Natural Sciences and Engineering Research Council of Canada (NSERC) Postgraduate Scholarship and a University of Saskatchewan Graduate Fellowship. Further support was provided by an NSERC Operating Grant (OGP0036712) to M. A. Ramsay and a Canadian Wildlife Service Grant in Aid of Research and a Department of Fisheries and Oceans Science Subvention Grant to M. A. Ramsay and K.A.H. We thank P. Amarualik, J. Amarualik, M. Bergmann, M. Graham, P. Breucker, H. Hop, T Siferd, and R. Martin for their help in the field. M. Curtis, P. Frank and J. Topping identified invertebrates and N. Grant helped with illustrations. C. van Kessel allowed K.A.H to use the stable-isotope facility at the Department of Soil Science, University of Saskatchewan, and G. Swerhone provided invaluable help with sample preparation. M. A. Ramsay and 4 anonymous reviewers provided useful comments on an earlier draft of the manuscript

\section{LITERATURE CITED}

Alexander, V. (1974). Primary productivity regimes of the nearshore Beaufort Sea with reference to potential roles of ice biota. In: Reed, J. C., Sater, J. E. (eds.) The coast and shelf of the Beaufort Sea. Arct. Inst. N. Amer., Arlington, p. 609-632

Attwood, C. G. Peterson, W. T (1989). Reduction in fecundity and lipids of the copepod Calanus australis (Brodskii) by strongly pulsed upwelling. J. exp. mar. Biol. Ecol. 129: $121-131$

Bain, H., Sekerak, A.D. (1978). Aspects of the biology of Arctic cod, Boreogadus saida, in the central Canadian Arctic. Unpubl. Rep. for Polar Gas Project by LGL Ltd, Toronto

Bohn, A., McElroy, R. O. (1976). Trace metals (As, Cd, Cu, Fe and $\mathrm{Zn}$ ) in Arctic cod, Boreogadus saida, and selected zooplankton from Strathcona Sound, northern Baffin Island. J. Fish. Res. Bd Can. 33: 2836-2840

Bradstreet, M. S. W., Brown, R. G. (1985). Feeding ecology of the Atlantic Alcidae. In: Nettleship, D. N. (eds.) The Atlantic Alcidae. Academic Press, London, p. 263-318

Bradstreet, M. S. W., Cross, W. (1982). Trophic relationships at high Arctic ice edges. Arctic 35: 1-12

Bradstreet, M. S. W., Finley, K. J., Sekerak, A. D., Griffiths, W B., Evans, C. R., Fabijan, M., Stallard, H. E. (1986). Aspects of the biology of Arctic cod (Boreogadus saida) and its importance in Arctic marine food chains. Can. Tech. Rep. Fish. Aquat. Sci. No. 1491, 193 p

Bremner, J. M., van Kessel, C. (1990). Appraisal of the nitrogen-15 natural abundance method for quantifying dinitrogen fixation. Soil Sci. Soc. Am. J. 54: 404-411

Conover, R. J., Cota, G. F. (1985). Balance experiments with Arctic zooplankton. In: Cray, J. S., Christanson, M. E. (eds) Marine biology of polar regions and effects of stress on marine organisms. John Wiley and Sons Ltd, New York, p. $217-236$ 
DeNiro, M. J., Epstein, S. (1978). Influence of diet on the distribution of carbon isotopes in animals. Geochim. Cosmochim. Acta 42: 495-506

Dickson, M. L. (1986). A comparative study of the pelagic food chains in two Newfoundland fjords using stable carbon and nitrogen isotope tracers. M.Sc. thesis, Memorial University of Newfoundland, St. John's

Dunton, K. H., Saupe, S. M., Golikov, A. N., Schell, D. M. Schonberg, S. V. (1989). Trophic relationships and isotopic gradients among arctic and subarctic marine fauna. Mar Ecol. Prog. Ser 56: 89-97

D'yakonov, A. M. (1950). Sea stars (asteroids) of the USSR seas. Keys to the fauna of the USSR, Zoological Institute of the Academy of Sciences of the USSR, No. 34

Finley, K. J. (1978). Behaviour and densities of ringed seals (Phoca hispida) during haul out in the high Arctic, June 1977. Report by LGL Ltd, Toronto

Finley, K. J., Evans, C. R. (1983). Summer diet of the bearded seal (Erignathus barbatus) in the Canadian high Arctic. Arctic 36: 82-89

Finley, K. J., Gibb, E. J. (1982). Summer diet of the narwhal (Monodon monoceros) in Pond Inlet, northern Baffin Island. Can. J. Zool. 60: 3353-3363

Fry, B. (1988). Food web structure on Georges Bank from stable C, N and S isotopic compositions. Limnol. Oceanogr. 33: 1182-1190

Fry, B., Sherr, E.B. (1988). $\delta{ }^{13} \mathrm{C}$ measurements as indicators of carbon flow in marine and freshwater ecosystems. In Rundel, P. W., Ehleringer, J. R., Nagy, K. A. (eds.) Stable isotopes in ecological research. Springer Verlag, New York, p. 196-229

Gaston, A. J., Nettleship, D. N. (1981). The thick-billed murres of Prince Leopold Island. Can. Wildl. Serv. Monogr. No. 6, Ottawa

Gormly, J. R., Sackett, W. M. (1977). Carbon isotope evidence for the maturation of marine lipids. Adv. org. Geochem. 1975: 321-340

Grebmeier, J. M., McRoy, C. P., Feder, H. M. (1988). Pelagicbenthic coupling on the shelf of the northern Bering and Chukchi Seas. I. Food supply source and benthic biomass Mar Ecol. Prog. Ser. 48: 57-67

Haines, E. B. (1976). Relation between the stable carbon isotope composition of fiddler crabs, plants, and soils in a salt marsh. Limnol. Oceanogr 21 880-882

Haines, E. B., Montague, C. L. (1979). Food sources of estuarine invertebrates analysed using ${ }^{13} \mathrm{C} /{ }^{12} \mathrm{C}$ ratios. Ecology 60: 48-56

Hammill, M. O., Smith, T G. (1991). The role of predation in the ecology of the ringed seal in Barrow Strait, Northwest Territories, Canada. Mar. Mammal Sci. 7: 123-135

Harrigan, P., Zieman, J. C., Macko, S. A. (1989). The base of nutritional support for the gray snapper (Lutjanus griseus) an evaluation based on a combined stomach content and stable isotope analysis. Bull. mar. Sci. 44: 65-77

Head, E. J. H., Harris, L. R., Abou Debs, C. (1985). Effect of daylength and food concentration on in situ diumal feeding rhythms in Arctic copepods. Mar. Ecol. Prog. Ser. 24 $281-288$

Head, E. J. H., Bedo, A., Harris, L. R. (1988). Grazing, defecation and excretion rates of copepods from inter-island channels of the Canadian Arctic archipelago. Mar. Biol 99: 333-340

Hobson, K. A., Clark, R. G. (1992). Assessing avian diets using stable isotope analysis. II: Factors influencing diet-tissue fractionation. Condor 94: 189-197

Hobson, K. A., Montevecchi, W A. (1991). Stable isotopic determinations of trophic relationships of great auks Oecologia $87 \cdot 528-531$
Hobson, K. A., Welch, H. E. (in press). Observations of for aging northern fulmars (Fulmarus glacialis) in the Canadian high Arctic. Arctic

Hobson, K. A. Sealy, S. G. (1991). Marine protein contributions to the diet of northern saw-whet owls on the Queen Charlotte Islands: a stable-isotope approach. Auk 108: $437-440$

Lee, R. F., Hirota, J. (1973). Wax esters in tropical zooplankton and nekton and the geographical distribution of wax esters in marine copepods. Limnol. Oceanogr 18: 227-239

McConnaughey, T., McRoy, C. P. (1979). Food-web structure and the fractionation of carbon isotopes in the Bering Sea. Mar Biol. 53: 257-262

Mills, E. L., Pittman, K., Tan, F. C. (1984). Food-web structure on the Scotian Shelf, eastern Canada: a study using ${ }^{13} \mathrm{C}$ as a food-chain tracer. Rapp. P.-v. Réun. Cons. int. Explor Mer 183: 111-118

Minagawa, M. Wada, E. (1984). Stepwise enrichment of ${ }^{15} \mathrm{~N}$ along food chains: further evidence and the relation between $\delta^{15} \mathrm{~N}$ and animal age. Geochim. Cosmochim. Acta 48: $1135-1140$

Mizutani, H., Kabaya, Y., Wada, E. (1991). Nitrogen and carbon isotope compositions relate linearly in cormorant tissues and its diet. Isotopenpraxis 4: 166-168

Monteiro, P. M. S., James, A. G., Sholto-Douglas, A. D., Field, J. G. (1991). The $\delta^{13} \mathrm{C}$ trophic position isotope spectrum as a tool to define and quantify carbon pathways in marine food webs. Mar. Ecol. Prog. Ser 78: 33-40

Ockelman, W K. (1958). The zoology of east Greenland; marine Tamallibranchiata. Meddr Gronland 122: 1-256

Owens, N. J. P. (1988). Natural variations in $15 \mathrm{~N}$ in the marine environment. Adv. mar Biol. 24: 389-451

Paine, R. T (1988). Food webs: road maps of interactions or grist for theoretical development? Ecology 69: 1648-1654

Parker, P. L. (1964). The biogeochemistry of the stable isotopes of carbon in a marine bay. Geochim. Cosmochim. Acta 28: 1155-1164

Porter, L. K., O'Dean, W. A. (1977). Apparatus for preparing nitrogen from ammonium chloride for nitrogen-15 determinations. Analyt. Chem. 45: 514-516

Rau, G. H. (1982). The relationship between trophic level and stable isotopes of carbon and nitrogen. In: Bascom, W (ed.) Coastal water research project biennial report for the years 1981-1982. S. Calif. Water Res. Proj., Long Beach, p $143-148$

Rau, G. H., Ainley, D. G., Bengtson, J. L., Torres, J. J., Hopkins, T. L. (1992). ${ }^{15} \mathrm{~N} /{ }^{14} \mathrm{~N}$ and ${ }^{13} \mathrm{C} /{ }^{12} \mathrm{C}$ in Weddell seabirds seals, and fish: implications for diet and trophic structure. Mar. Ecol. Prog. Ser. 84: 1-8

Rau, G. H., Anderson, N. H. (1981). Use of ${ }^{13} \mathrm{C}:{ }^{12} \mathrm{C}$ to trace dissolved and particulate organic matter utilization by populations of an aquatic invertebrate. Oecologia 48 : $19-21$

Rau, G. H., Sweeney, R. E., Kaplan, I. R. (1982). Plankton ${ }^{13} \mathrm{C} /$ ${ }^{12} \mathrm{C}$ ratio changes with latitude: Differences between northern and southern oceans. Deep Sea Res. 29: 1035-1039

Rau, G. H., Mearns, A. J., Young, D. R., Olson, R. J., Schafer H. A., Kaplan, I. R. (1983). Animal ${ }^{13} \mathrm{C} /{ }^{12} \mathrm{C}$ correlates with trophic level in pelagic food webs. Ecology 64: 1314-1318

Reeves, R. R., Tracey, S. (1980). Monodon monoceros. Mamm. Species 127: 1-7

Ridgeway, S. H., Bowers, C. A., Miller, D., Schultz, M. L. Jacobs, C. A., Dooley, C. A. (1984). Diving and blood oxygen in the white whale. Can. J. Zool. 63: 2349-2351

Sanger, G. A. (1987). Trophic levels and trophic relationships of seabirds in the Gulf of Alaska. In: Croxall, J. P. (ed.) 
Seabirds; feeding ecology and role in marine ecosystems. Cambridge Univ. Press, Cambridge, p. 229-257

Schell, D. M., Saupe, S. M., Haubenstock, N. (1989). Bowhead whale (Balaena mysticetus) growth and feeding as estimated by $\delta{ }^{13} \mathrm{C}$ techniques. Mar. Biol. 103: 433-443

Sergeant, D. E. Hay, K. (1978). Migratory sea mammal populations in Lancaster Sound. ESCOM Report No. AI-21. Environmental-Social Program Northern Pipelines. Dept. Indian and Northern Affairs, Ottawa, $31 \mathrm{pp}$.

Sholto-Douglas, A. D., Field, J. G., James, A. G., van der Merwe, N. J. (1991). ${ }^{13} \mathrm{C} /{ }^{12} \mathrm{C}$ and ${ }^{15} \mathrm{~N} /{ }^{14} \mathrm{~N}$ isotope ratios in the Southern Benguela Ecosystem: indicators of food web relationships in different size-classes of plankton and pelagic fish; differences between fish muscle and bone collagen tissues. Mar. Ecol. Prog. Ser 78: 23-32

Stirling, I., McEwan, E. H. (1975). The caloric value of whole ringed seals (Phoca hispida) in relation to polar bear (Ursus maritimus\} ecology and hunting behavior. Can. J. Zool. 53: 1021-1027

This article was presented by D. C. Schneider, St. John's, Nfld, Canada
Swerhone, G. D. W., Hobson, K. A., Van Kessel, C., Boutton, T W. (1991). An economical method for preparation of plant and animal tissue for $\delta^{13} \mathrm{C}$ analysis. Comm. Soil. Sci. Plant Anal. 22: 177-190

Tan, F. C., Strain, P. M. (1983). Sources, sinks and distribution of organic carbon in the St. Lawrence estuary, Canada Geochim. Cosmochim. Acta 47 125-132

Tieszen, L. L., Boutton, T W., Tesdahl, K. G., Slade, N. A. (1983). Fractionation and turnover of stable carbon isotopes in animal tissues: implications for $\delta^{13} \mathrm{C}$ analysis of diet. Oecologia 57:32-37

Wada, E., Terazaki, M., Kabaya, Y., Nemoto, T (1987). ${ }^{15} \mathrm{~N}$ and ${ }^{13} \mathrm{C}$ abundances in the Antarctic Ocean with emphasis on the biogeochemical structure of the food web. Deep Sea Res. 34: 829-841

Welch, H. E., Bergmann, M. A., Siferd, T D., Martin-Bergmann, K. A., Curtis, M. F., Crawford, R. E., Conover, R. J., Hop, H. (in press). Energy flow the marine ecosystem of the Lancaster Sound Region, Canadian Arctic. Arctic

Manuscript first received: October 1, 1991

Revised version accepted: May 7, 1992 